\title{
Application of Rheology for Energy Saving Air Conditioning System
}

\author{
Hiromoto USUI $^{*}$ and Takashi SAEKI ${ }^{* *}$ \\ ${ }^{*}$ Headquarters of Kobe University, 1-1Rokkodai, Nada, Kobe 657-8501, Japan
${ }^{* *}$ Graduate School of Science and Engineering, Yamaguchi University, 2-16-1 Tokiwadai, Ube 755-8611, Japan
}

\begin{abstract}
Surfactant drag reduction is well known as the energy saving technology which is able to cause drastic reduction of pumping power during the fluid transportation. The combination of certain type of cationic surfactant with suitable counter ion is often chosen as the drag reduction agents. Power saving up to $70 \sim 80 \%$ is available in straight pipe line system by using surfactant additives. Design problem, in particular, the scale up law in surfactant drag reduction system was solved by using the modified viscoelastic damping factor model along with the measurements of nonlinear viscoelastic properties of surfactant solution. Based on the prediction of the proposed model, it was demonstrated that the surfactant drag reduction technology is promising to construct the large scale energy saving system for air conditioning. Up to now, over 150 sites of building air conditioning had adopted the surfactant drag reduction in Japan, and the practical pumping energy reduction had been reported as $20 \sim 50 \%$ compared with the case of no drag-reducing agent.
\end{abstract}

Key Words: Drag reduction/ Surfactant/ Turbulent flow/Viscoelastic fluid

\section{省エネルギー型空調システムへのレオロジーの応用}

\author{
薄井 洋基 ${ }^{*}$, 佐伯 隆 ${ }^{* *}$
}

(原稿受理：2010 年 1 月 25 日)

\section{1. はじめに}

地球温暖化防止のために, 国を挙げて $\mathrm{CO}_{2}$ 排出量の削減 に取り組んでいるが, 削減目標達成のために国民に負担が 重く課せられることが危惧されている. 省エネルギー技術 の研究開発と実用化を多面的に展開して, $\mathrm{CO}_{2}$ 排出量の削減 を実現することが急務となっている.

レオロジーは多様な物質の変形と流動を取り扱う学問であ り, その対象とする物質は, 日常生活で重要な材料, プラス チック, セラミクスはもとより, ペイントや化粧品・洗剤, 血液・血管・関節液・骨などの医学生理学関係, 歯ごたえ・ 咽喉越しなど食感の良い食品など，非常な広範囲にわたって いる。それらの物質の中で，界面活性剂は溶媒中で様々なミ セルの形態を取り, そのことが溶液のレオロジー特性を変化 させて種々の興味ある効果を発現させることが知られてい る. その応用の一つとして, 空調用冷媒にある種の界面活性 剂を添加して冷媒搬送動力を低減させ, 省エネルギー型空 調システムを実現させようとする試みが続けられてきた。

本稿では，著者の研究室で行ってきた省エネルギー型空調 システムの基礎研究とそこで応用されるレオロジーの現象, および本技術の実用化と普及について述べることとする.

* 神戸大学本部, $\bar{\top}$ 657-8501 兵庫県 神戸市 灘区 六甲台町 1-1

Tel: 078-803-5002, Fax: 078-803-5009, E-mail: usui@kobe-u.ac.jp

** 山口大学大学院 理工学研究科環境共生系専攻, T 755-8611 山口県 宇部市常盤台 2-16-1 Tel \& Fax: 0836-85-9242, E-mail: saeki@yamaguchi-u.ac.jp
2. 通常のビル空調，地域冷暖房システム

ビル空調システムの一例を Fig. 1 に示す. 熱源として吸収 式冷凍機などが使用され，冷房時には約 $10{ }^{\circ} \mathrm{C}$ の冷水を作り， 搬送ポンプによってビルの各階に送る。そして，空気調和 機 (Air Handling Unit) で冷水と空気の熱交換によって冷風を 作り，室内の空調を行なう。これによって通常，冷水の温 度は数 ${ }^{\circ} \mathrm{C}$ 上昇し, 冷凍機に戻る。冬季には温水を製造して,

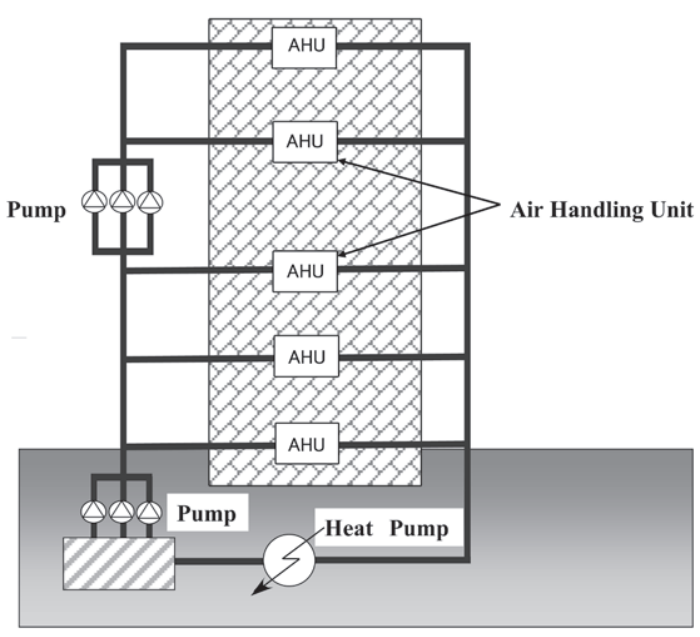

Fig. 1. Building air conditioning system. 
これを循環させて暖房に使用する。一方, 一定地域内の複 数の建物や施設に熱を供給するものが地域冷暖房システム である. 大規模な熱源装置を備えたエネルギーセンターで 大量の冷水または温水を作り, これを地下のパイプライン で地域の各ビルに輸送し，冷暖房に使用する。

\section{3. 界面活性剤の自己組織化による紐状ミセルの形 成とそのレオロジー特性}

ある種の陽イオン界面活性剤と対イオンを組み合わせた 系では紐状ミセルを形成することが知られており，レオロ ジーの分野では臭化セチルトリメチルアンモニウム (CTAB) とサリチル酸ナトリウムの系が良く用いられる. ${ }^{1}$ また, 両性 界面活性剤も同様の紐状ミセルを形成する。薄井ら ${ }^{2)}$ は塩化 セチルトリメチルアンモニウム (CTAC) に同量のサリチル酸 ナトリウムを加えた系について, Fig. 2 に示す特異な流動特 性を報告した。すなわち, 見掛け粘度があるせん断速度域 でジャンプアップし，さらに高せん断を加えた後，徐々に せん断速度を減少させると高い粘度レベルを保つ，という 履歴現象である。

この現象は，SIS (shear induced state) と呼ばれ，界面活性剤 水溶液が強い粘弾性を示す原因と考えられている.

\section{4. 円管内乱流における抵抗低減効果}

粘弾性流体の乱流においては，添加された鎖状高分子， 界面活性剂ミセルなどと乱流渦との相互作用によって乱流 微小渦の粘性消散が阻害され，エネルギー消散が少ない状 態で流体輸送が可能になるため, 低消費動力の流体輸送が 可能になるといわれている.このような現象を抵抗低減(Drag Reduction) 効果とよぶ. 界面活性剤による抵抗低減効果の発 現メカニズムについては，添加剤によって流れが制御され ることが予測され ${ }^{3-5}$, 流れの計測から, その構造変化が議

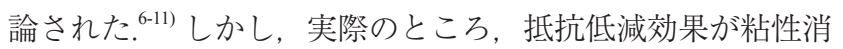
散の阻害によって引き起こされているとの結論は得られて おらず, 一方, 乱流変形によって蓄えられた弾性エネルギー が流れに垂直な方向の乱流混合によって輸送され，異なっ た位置において弾性エネルギーを放出するために生じる現

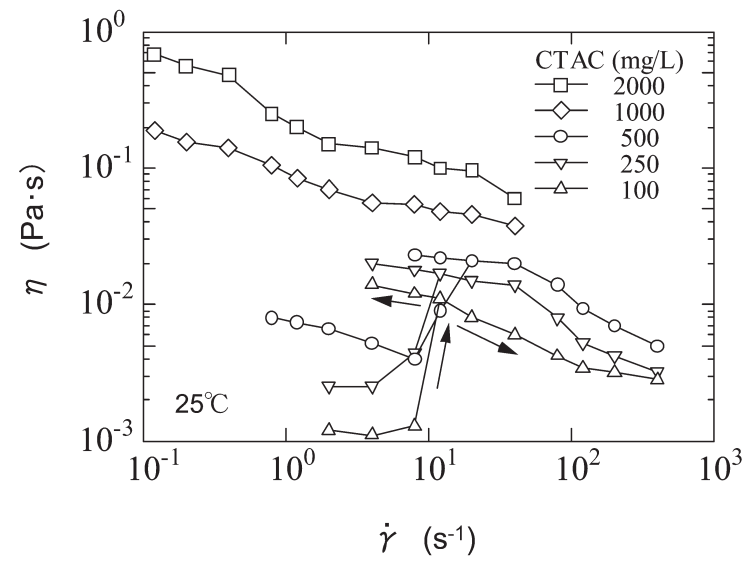

Fig. 2. Shear induced state of CTAC and sodium salicylate system.
象であるともいわれ，現在まで論争が続いている.

抵抗低減効果の原因究明は今後の課題であるとしても, 抵抗低減は特段のノウハウ無しに, その効果を通常の実験 室レベルの装置で容易に確かめることができる。Fig. 3 に CTAC- サリチル酸ナトリウム系における円管内乱流抵抗低 減効果を示す。ここで, 縦軸は摩擦係数, $f$, 横軸はレイノ ルズ数，Re，であり，それぞれ(1)，(2)式で定義される。こ こで, $\Delta \mathrm{P}$ は圧力損失, $L$ は管長, $D$ は管径, $U$ は平均流速, $\rho$, $\eta$ はそれぞれ溶媒（水）の密度，および粘度である。 $f$ は $\Delta$ に比例し，Reは流速に比例すると考えてよい.

$$
\begin{aligned}
& f=\frac{\Delta P}{2(L / D)\left(\rho U^{2}\right)} \\
& \operatorname{Re}=\frac{\rho D U}{\eta}
\end{aligned}
$$

罒中の実線はニュートン流体の層流における摩擦係数の理 論式 $(f=16 / \mathrm{Re})$, および乱流における実験式 $\left(f=0.0791 \mathrm{Re}^{-0.25}\right.$, Blasius の式）である。管径，管長，流量が一定の場合，摩 擦係数は界面活性剤を添加する前より最大で約 $70 \%$ 低減 することがわかる。ここで，図に示したCTAC- サリチル酸 ナトリウム系の水溶液は, 冷房に用いられる冷水の温度域 $\left(10^{\circ} \mathrm{C}\right.$ 前後) では抵抗低減効果を示さないことが分かる。さ らに $60^{\circ} \mathrm{C}$ から $65^{\circ} \mathrm{C} に$ 液温が上昇する間で抵抗低減効果が 失われることもわかる。 そこで，著者らはビル空調用として 最適な抵抗低減剤を探索，スクリーニングし ${ }^{12}$, Fig. 4 に示 す構造の塩化ビスヒドロキシエチルメチルアンモニウム（商 品名：エソカード $\mathrm{O} / 12$ ，ライオンアクゾ(株)）とサリチル 酸ナトリウムの系を選定した。 Fig.5 は $500 \mathrm{mg} / \mathrm{L}$ のエソカー

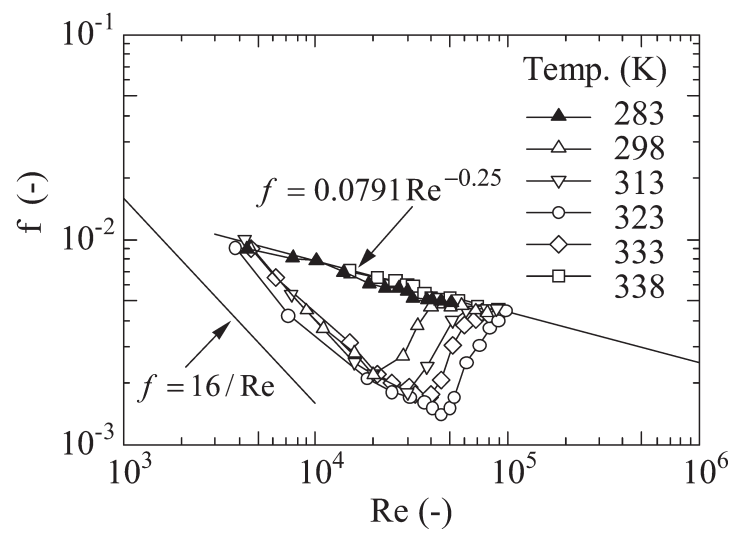

Fig. 3. Drag reduction effect for $500 \mathrm{mg} / \mathrm{L}$ CTAC and $300 \mathrm{mg} / \mathrm{L} \mathrm{NaSal}$ solution.

$$
\underset{\substack{\mathrm{CH}_{2} \mathrm{CH}_{2} \mathrm{OH} \\ \text { Ethoquad } \mathrm{O} / 12}}{\mathrm{C}_{18} \mathrm{H}_{35}-\mathrm{N}^{+}-\mathrm{CH}_{3}} \mathrm{Cl}_{\text {Sodium salicylate }}^{\mathrm{CH}_{2} \mathrm{CH}_{2} \mathrm{OH}}
$$

Fig.4. Molecular structure of drag-reducing additives. 
ド $\mathrm{O} / 12$ に対し, サリチル酸ナトリウムを $300 \mathrm{mg} / \mathrm{L}$ 添加して 調製した水溶液の抵抗低減効果を示したものである。ここ で，上述したように溶液は複雑な非ニュートン粘性を示すた め, レイノルズ数の算出には溶媒（水）の粘度を用いてい

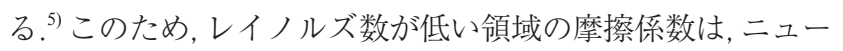
トン流体の層流の式には漸近しない.レイノルズ数が高い 領域に注目すると, 本添加剤は $0{ }^{\circ} \mathrm{C}$ 近くの低温域から通常 のビル空調における暖房用温水域まで, 抵抗低減効果を発 揮することが確認できる. ${ }^{13)}$

Fig.3,5に示した抵抗低減効果は実験装置の直管部分で測 定された結果であるが, 実際の空調システムでは, ベンド, エルボ, 拡大縮小部, バルブなどの管付属物があり, これ らの部分で抵抗低減効果が低下する。事実, ビル空調の配 管系による抵抗低減効果の実測データから，20～50\%の動 力低減効果が発現することが確認されている. ${ }^{14)}$ 通常, 冷水 または温水の搬送に必要なポンプ動力は, 空調システム全 体の消費エネルギーの $10 \%$ 程度である. すなわち, 抵抗低 減効果によってポンプ動力の省エネルギー化を図れば, 空 調システムに投入するエネルギーの $2 \sim 5 \%$ を削減するこ とができるといえ，この数值は省エネルギー型空調システ ムに応用することの有効性を示している.

\section{5. 抵抗低減現象における管径効果}

抵抗低減効果は媒体に添加された鎖状高分子, または界 面活性剤ミセルと乱流渦との相互作用により発現するもの である，実用化に際して，大口径の管内の乱流では管径の増 大に伴い乱流渦のスケール, 乱流エネルギーレベルなどが 大きくなる，一方，添加剤の大きさは一定であるため, 希 薄高分子溶液については, 管径が大きくなると抵抗低減効 果が減少する, いわゆる, 管径効果が存在することが知ら れていた，石油パイプライン輸送における実用化研究では， 鎖状高分子の分子量を極端に大きくして大口径管でも抵抗 低減効果が発現する技術が開発された，具体的には，原油に 可溶なオレフィン系鎖状高分子（分子量は 4000 万程度）の 濃厚溶液をポンプステーションの出口で管内に注入する方 法が採られた.15)

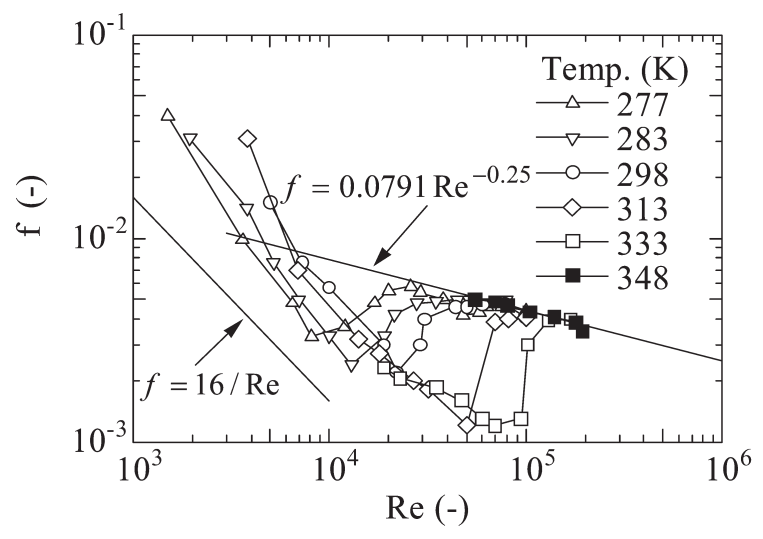

Fig. 5. Temperature dependence of drag reduction effect for $500 \mathrm{mg} / \mathrm{L}$ Ethoquad $\mathrm{O} / 12$ and $300 \mathrm{mg} / \mathrm{L} \mathrm{NaSal}$. solution.
一方, 界面活性剂を用いた省エネルギー型空調システム においても，ビル空調では口径が数百 $\mathrm{mm}$ の管が使われて おり, 地域冷暖房システムでは口径が $1 \mathrm{~m}$ 程度の場合もある。 界面活性剂を用いた省エネルギー型空調システムを実用化 するためには, 大口径管であっても抵抗低減効果が発現す るのかどうかを確認し, スケールアップ則を確立すること が重要な課題であった。

Fig. 6 は配管径の異なる抵抗低減効果の実験結果であり, 大口径 $(80 \mathrm{~mm}, 150 \mathrm{~mm})$ の八塩ら ${ }^{16)}$ の実験データとともに比 較したものである. ${ }^{17)}$ 図より口径 $150 \mathrm{~mm}$ の管でも抵抗低減 効果を示すことが確認できる.

Usui $ら^{17)}$ は界面活性剤による抵抗低減効果のスケール アップ則を以下のようにモデル化した，界面活性剤により紐 状ミセルを形成する系においては，マックスウェルモデル によりそのレオロジー特性が表現できることがわかってい る。しかしながら, 乱流状態に無関係な, 単一の緩和時間で はスケールアップ則を組み立てることができない. そこで, Fig.7 に示すように, 一定せん断を印加して SIS の状態を発 生させた後, せん断速度を一定速度で減少させ, 応力の応 答を測定した。ここで，せん断速度の減少率は $0.04 \sim 3.5 \mathrm{~s}^{-2}$ の範囲で変化させた。ここで, マックスウェルモデルは,

$$
\tau+\lambda \frac{d \tau}{d t}=\eta \dot{\gamma}
$$

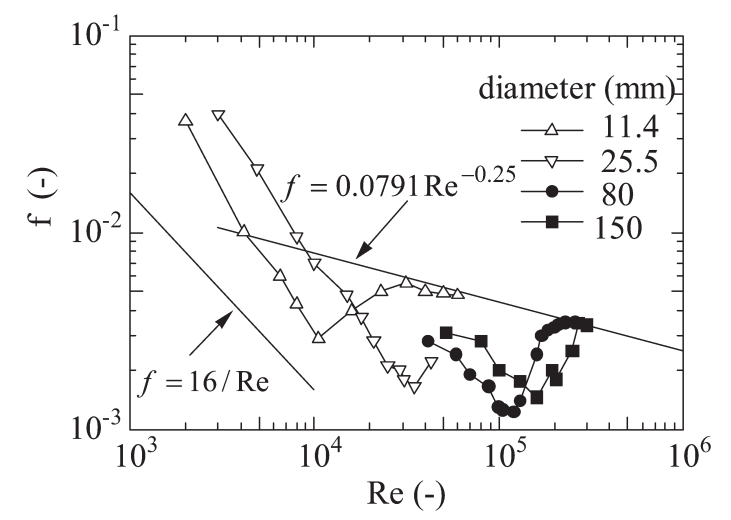

Fig. 6. Pipe-diameter effect for drag reduction with $500 \mathrm{mg} / \mathrm{L}$ Ethoquad $\mathrm{O} / 12$ and $300 \mathrm{mg} / \mathrm{L}$ NaSal. solution at $280 \mathrm{~K}$.

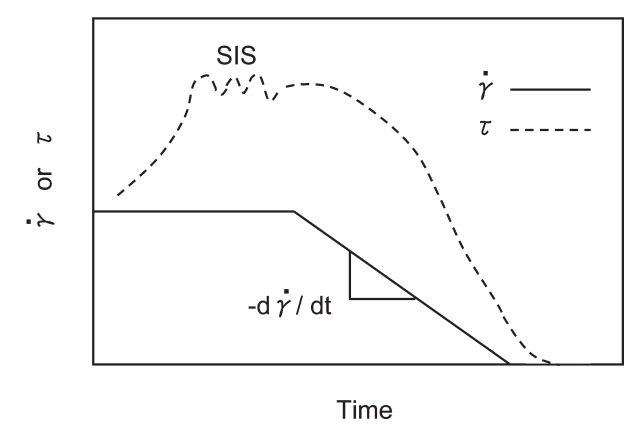

Fig. 7. Shear history and stress response for the measurement of relaxation time and SIS. 
であり，この記憶関数は次式で表される.

$$
g(t)=(\eta / \lambda) \exp (-t / \lambda)
$$

時間, $t$, がゼロまでは一定せん断速度が持続しており, $t$ が 正の領域ではせん断速度が一定の減少率で減少するとして, 応力, $\tau$, は畳み込み積分によって, 次式で計算される。

$$
\begin{aligned}
\tau & =\int_{-\infty}^{0} \dot{\gamma}_{0} g\left(t-t^{\prime}\right) d t^{\prime}+\int_{0}^{t}\left[-(d \dot{\gamma} / d t) t+\dot{\gamma}_{0}\right] g\left(t-t^{\prime}\right) d t^{\prime} \\
& =\dot{\gamma}_{0}-\frac{d \dot{\gamma}}{d t} \eta t+\frac{d \dot{\gamma}}{d t} \eta \lambda[1-\exp (-t / \lambda)]
\end{aligned}
$$

緩和時間, $\lambda$, を仮定して応力の時間変化を計算すると, 実 験結果と良く一致する緩和時間を求めることができる。工 ソカード $\mathrm{O} / 12$ とサリチル酸ナトリウム系に対して, 得られ た入の結果を Fig. 8 に示す.

緩和時間はせん断速度の変化率の関数であり, 次の実験 式で表現された

$$
\lambda=2\left(\frac{d \dot{\gamma}}{d t}\right)^{-0.8}+0.8
$$

一方，界面活性剤溶液は Fig. 2 に示したようにSIS によ る複雑なレオロジー特性を示す。そこで, $500 \mathrm{mg} / \mathrm{L}$ のエソ カード $\mathrm{O} / 12$ に $300 \mathrm{mg} / \mathrm{L}$ のサリル酸ナトリウムを添加した 水溶液について, 回転粘度計のせん断速度を段階的に上昇さ せ, 各せん断速度での平衡応力を測定し, この応力值より決 定される見かけ粘度をせん断速度に対して得た。この結果 をFig.9に示した。 また, 高せん断域での測定は細管粘度計 を使用し, Krieger-Maronの方法により, せん断応力とせん断 速度の関係を得て, 図中に○で示した。 図より, 温度の低 い領域 (282 293 K) では, shear thinning な特性に加えて, せ ん断速度が 1 〜 $30 \mathrm{~s}^{-1}$ において, 見かけ粘度の急激な上昇が 観測されたが，このレベルは溶液温度の上昇とともに低下し た。 またせん断速度が $10^{4} \mathrm{~s}^{-1}$ 以上の領域では, 溶液の粘度は 水と同程度になった。

せん断速度と温度, $T$, に対する見かけ粘度の非線形な関 係については, 修正 Bird-Carreau model と Arrhenius タイプの

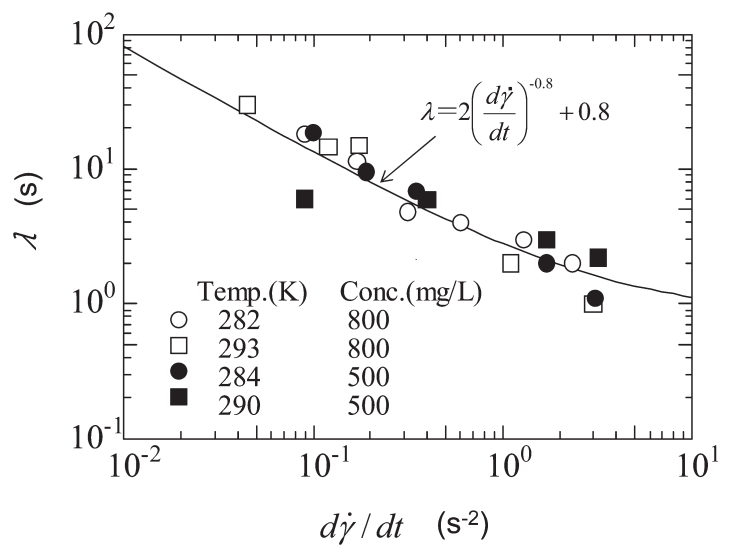

Fig. 8. Relaxation time determined by the stress relaxation experiments.
温度依存性を用いることによってうまく表現でき, 最終的に 以下の式が得られた。

$$
\eta=\eta_{0}\left[1+(t \dot{\gamma})^{2}\right]^{(n-1) / 2}+\eta_{\infty}
$$

ここで

$$
\begin{aligned}
\eta_{0} & =\exp (-102+29200 / T) \\
t & =\exp (-108+31200 / T) \\
\eta_{\infty} & =0.00127 \exp [2190(1 / T-1 / 291)]
\end{aligned}
$$

である. $n$ は power law index で一定值 $(=0.005)$ をとる. $\eta_{0}$ は ゼロせん断粘度, $\eta_{\infty}$ は高せん断域での漸近粘度, $t$ は natural time である。 $\eta_{\infty}$ の温度依存性は水と同様の挙動であると仮 定した. (7)式で算出した粘度の值を Fig. 9 に実線で示したが, この結果は実験值とよく一致しており，後述する抵抗低減 モデルにおいて，界面活性剤の粘度を表すために使用する こととした。

Usui ら ${ }^{17)}$ は粘弾性により乱流拡散が減衰されるとして, van Driest タイプの乱流モデルを粘弾性流体に拡張した。こ の拡張モデルにおいて, 運動量の乱流拡散係数, $\varepsilon_{\mathrm{m}} / v$, は (8) 式で表され，これを円管内の応力分布式に代入し，非ニュー トン粘性を考慮して積分することにより，速度分布，摩擦 係数などが予測できる.

$$
\frac{\varepsilon_{m}}{v}=f n\left(y^{+}, R^{+}\right)^{2} D F^{2} \frac{d u^{+}}{d y^{+}}
$$

ここで $f n\left(y^{+}, R^{+}\right)$はニュートン流体の乱流混合距離であり, 次式で表される。

$$
f n\left(y^{+}, R^{+}\right)=0.4 y^{+}-0.44 \frac{\left(y^{+}\right)^{2}}{R^{+}}+0.24 \frac{\left(y^{+}\right)^{3}}{\left(R^{+}\right)^{2}}-0.06 \frac{\left(y^{+}\right)^{4}}{\left(R^{+}\right)^{3}}
$$

また粘弾性減衰係数，DF，は次式で与えられる。

$$
D F=1-\exp \left(\frac{-y^{+}}{26} \sqrt{-\alpha+\sqrt{\alpha^{2}+1}}\right)
$$

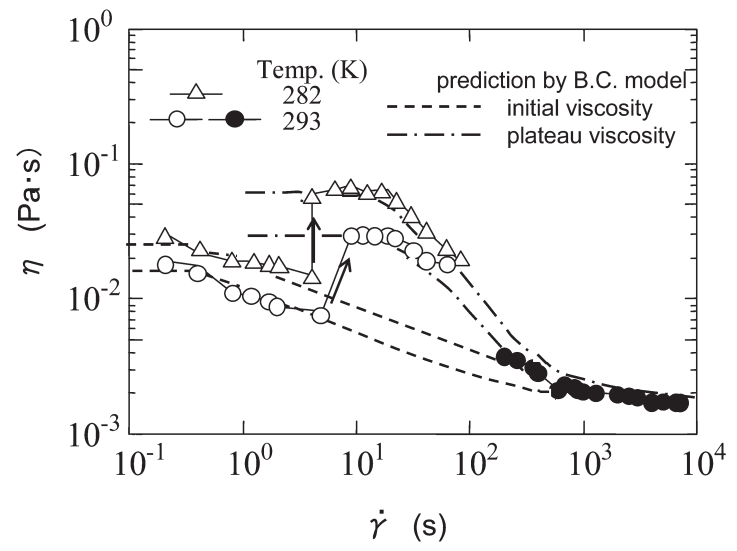

Fig. 9. Apparent viscosity of $500 \mathrm{mg} / \mathrm{L}$ Ethoquad $\mathrm{O} / 12+300 \mathrm{mg} / \mathrm{L}$ NaSal. solution. 
$\alpha$ は動粘度, $v$, と壁摩擦速度, $u_{\tau}$, で次式のように無次元 化された緩和時間であり, 緩和時間 $\lambda$ は (6) 式で与えられる 相関式を用いた。

$$
\alpha=\frac{2 \lambda}{v}\left(\frac{u_{\tau}}{26}\right)^{2}
$$

なお, 流れ方向の速度, $u$, 壁からの距離, $y$, 管の半径, $R$, は $u_{\tau}$ と壁での動粘度, $v$, で,

$$
\begin{aligned}
& u^{+}=u / u_{\tau} \\
& y^{+}=y u_{\tau} / v \\
& R^{+}=R u_{\tau} / v
\end{aligned}
$$

と無次元化した。 非ニュートン流体に対しても, 管内流で の全応力分布は直線的であるので，以下の関係が成り立つ.

$$
\frac{\tau}{\tau_{w}}=\frac{\eta / \rho}{v} \frac{d u^{+}}{d y^{+}}+\frac{\varepsilon_{m}}{v} \frac{d u^{+}}{d y^{+}}=1-\frac{y^{+}}{R^{+}}
$$

ここで非線形粘度, $\eta$, は (7) 式で与えられる. 一方, $v$ は壁 面せん断速度での見かけ粘度より与えられる。界面活性剂 溶液の密度, $\rho$, は水の密度と等しいとした。(11) 式と (15) 式から管内乱流抵抗低減流れの速度分布は以下の (16) 式で 与えられる。

$$
u^{+}=\int \frac{2\left(1-y^{+} / R^{+}\right) d y^{+}}{\eta / \rho v+\sqrt{(\eta / \rho v)^{2}+4 f n\left(y^{+}, R^{+}\right)^{2} D F^{2}\left(1-y^{+} / R^{+}\right)}}
$$

これらの式を用いて, 以下の手順で計算を行った。はじめ に界面活性剂水溶液の基礎的な物性值として, せん断速度 に対する粘度の関係と緩和時間を実験から求める. 次に流 量を与えて壁せん断応力, $\tau_{w}$, の值を仮定する. 壁せん断速 度は次式で求める。

$$
u_{\tau}=\sqrt{\tau_{w} / \rho}
$$

管径方向の位置を $\Delta y$ の間隔で細分化したが，このとき，

$$
\Delta y^{+} \cong 1, \text { ただ }, \Delta y^{+}=\Delta y u_{\tau} / v
$$

の条件を満たすようにした，壁面でのスリップは起こらな いとすると, 局所の速度は (16) 式を積分することによって 計算できる，新しい格子点での速度を計算するには，ある 格子での速度を仮定し，壁に1つ近い格子での速度の差よ り局所速度勾配が得られる。この值を用いて局所の見かけ 粘度を (7) 式によって求め, その格子点の速度を(16) 式に よって求めた。局所速度の仮定值と計算值の相対誤差が $10^{-4}$ 以下になれば, 次の格子の計算を進め, 最終的に速度分布を 積分して流量を算出した。この值がはじめに与えた流量と異 なった場合は, 壁せん断応力の值を仮定し直し, 相対誤差が $1 \%$ 以内になるまで同様の手順で計算を繰り返した。摩擦係 数は壁せん断応力と速度分布から，以下の式で計算できる.

$$
f=\frac{\tau_{w}}{1 / 2 \rho<u>^{2}}
$$

ここで, $<u>$ は管断面平均速度である。

以上のようにして得られた摩擦係数のモデル予測結果を Fig. 10 において実験結果と比較した。なお，図中の $\uparrow$ 印は 抵抗低減効果が失われ始める壁せん断応力を $3.9 \mathrm{~Pa}$ と決定し たものである。これより，管径が $150 \mathrm{~mm}$ までの範囲では, スケールアップの計算結果が実験結果を良く説明できてい る. 図には, 実験データのない管径 $1000 \mathrm{~mm}$ の場合について, 算出した予測值も示した。このようなスケールアップ則の有 効性は，ビル空調，あるいは地域冷暖房システムの実用化 における省エネルギー効果を理論的に裏付けるものであり, 実用化を促進する上で有益であると考えられる。

\section{6. 界面活性剂による抵抗低減効果の実用化}

\section{1 配管抵抗低減剤の開発}

界面活性剂による抵抗低減効果は, 界面活性剤の泡立ち という問題から, 閉路水循環系への適用を対象とし, 当初, 一般の空調設備への適用が検討された。そして，上述した ように選定されたエソカード $\mathrm{O} / 12$ をベースとした配管抵抗 低減剤が開発された。ここで，配管設備においては，腐食 を防止するためしばしば防錆剂が使用される。Fig. 11 は市販 の防錆剤 A（モリブデン酸塩系）を添加したときの抵抗低 減効果に及ぼす影響を実験した結果である.14)ここで，縦軸 は次式で定義される抗力減少率, $D R \%$, である.

$$
D R \%=\frac{f_{\text {water }}-f_{\text {surfactant }}}{f_{\text {water }}} \times 100
$$

ここで, $f_{\text {water },} f_{\text {surfac tan } t}$ はそれぞれ水を流したとき，および界 面活性剤を流したときの摩擦係数である。防錆剤の添加と ともに抵抗低減効果が阻害されていくことが判る。この防 錆剂の推奨添加濃度は $700 \mathrm{mg} / \mathrm{L}$ とされており, 実際の循環 系で濃度管理が不十分であると，抵抗低減効果に負の影響 をもたらすことになる。市販のリン酸系や亜硝酸系の防錆

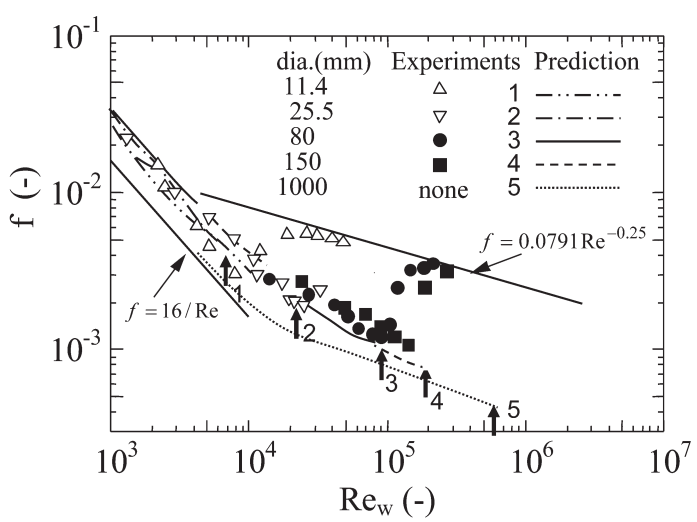

Fig. 10. Comparison of surfactant drag reduction data with the predictions of the present model for the aqueous solution of $500 \mathrm{mg} / \mathrm{L}$ Ethoquard O/12 $+300 \mathrm{mg} / \mathrm{L} \mathrm{NaSal}$. at $280 \mathrm{~K}$. Reynolds number $\mathrm{Re}_{w}$, is based on the wall shear viscosity. 
剂についでも, 同様の阻害傾向が見られた.これらの詳細 な組成は公開されておらず，阻害の原因物質を特定できな いが, 市販の防錆剂は管壁に付着したスケールの洗浄効果 を持たせるため, アニオン系の界面活性剤を含んでいる場 合が多い, との情報があり，これがエソカード $\mathrm{O} / 12$ （カチ オン系界面活性剤）のミセル形成に影響する一因であると 考えられる。

そこで, 数多くの防錆剤製品について, 抵抗低減効果へ の影響を調べるのではなく, 阻害のない防錆剤を含有した添 加剂が開発された。実際のところ, モリブデン酸ナトリウム, または亜硝酸ナトリウムのみを使用することで防錆は十分 であり, 抵抗低減効果を全く阻害しないことが確認された。

Fig.12 はエソカード O/12 をベースとし, 鉄, 銅, 亜鉛の 防錆効果を持つ LSP-01（エルエスピー協同組合）である. 水循環系の保有水量 $2 \mathrm{~m}^{3}$ に対し, 1 パック $10 \mathrm{~kg}$ の割合で添 加することにより, DR 効果と防錆効果が得られる.

\section{2 配管抵抗低減剤を使用した省エネルギー}

海外においては界面活性剂による抵抗低減効果の実設備 への応用は数例あるものの ${ }^{18)}$, 継続的な使用は行われてい ない. これには個々に理由があるが, 特に早くから抵抗低

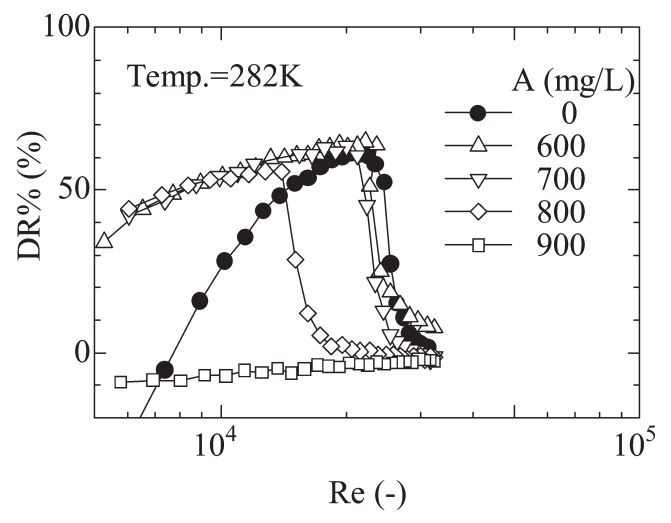

Fig. 11. Effect of a commercially available corrosion inhibitor, 'A', on the drag reduction caused by $500 \mathrm{mg} / \mathrm{L}$ Ethoquad $\mathrm{O} / 12$ and $300 \mathrm{mg} / \mathrm{L} \mathrm{NaSal}$.

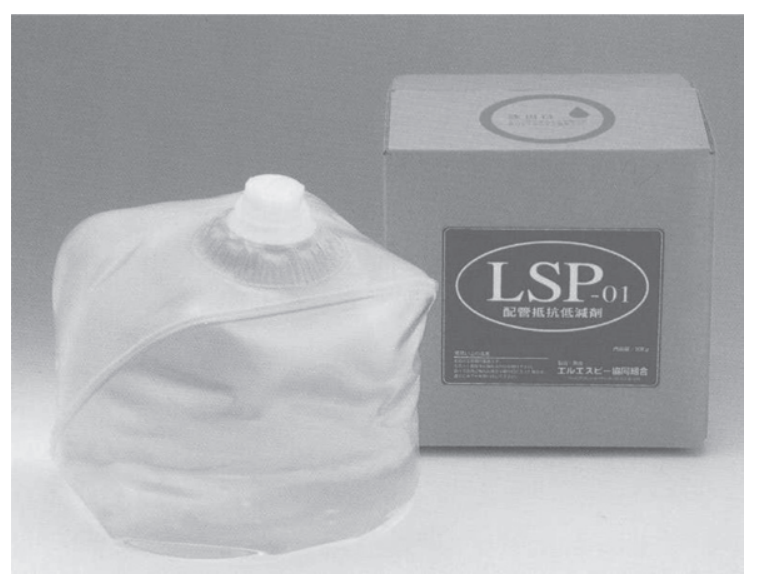

Fig. 12 Drag-reducing additive (LSP-01, LSP Cooperative Union).
減の研究が開始されたヨーロッパで実用化が進まないのは, 非イオン系界面活性剤を選定したことに一因がある。非イオ ン系には生分解性であるという環境面には望ましい性質が あるが, それがゆえに添加剤の安定性に問題があった。一方, 日本においては 1994 年に（財）周南地域地場産業振興セン ターの施設建物でわが国初の実証試験が行われた。 その後, 山口県周南市所有の設備で長期の実証試験が行われた. ${ }^{14)} こ$ こでは $5 \mathrm{~m}^{3}$ (保有水量) の循環水が, $15 \mathrm{~kW}$ のポンプで輸送

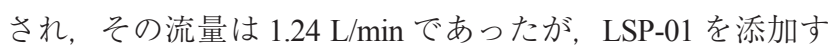
ることによって流量は $1.36 \mathrm{~L} / \mathrm{min}$ となった。すなわち, 摩擦 低減によって循環流量が $9.6 \%$ 増加した。ここで，ポンプに 設置したインバーターを使い, Fig. 13 に示す流量とインバー ターの設定周波数の関係をもとに, 添加前後の流量が一致 するように周波数が下げられた $(60 \mathrm{~Hz} \rightarrow 54 \mathrm{~Hz})$. この操作に より, 結果として約 $20 \%$ のポンプの消費電力が削減できた.

別の実施例として, 東京都内のテナント街の空調設備で は $7.5 \mathrm{~kW}$ のポンプ 2 台と $2.2 \mathrm{~kW}$ のポンプ 1 台で冷温水が循 環されていたが, LSP-01 を添加することにより, $2.2 \mathrm{~kW} の$ ポンプを停止しても同じ循環水量が得られた。

このように，配管抵抗低減剤は,

1) 循環系の流量増加

2) インバーターと併用したポンプの消費電力の削減

3) ポンプの台数減少による消費電力の削減 という目的で使用されている。

\section{3 抵抗低減効果の実機導入実績}

環境問題や省エネルギーに対する意識向上を受け，界面 活性剤による抵抗低減効果の国内における導入は 150 件を 越えている（2008 年末）。これには 30 階以上の高層ビルや 空港設備, 大規模店舗や総合病院, テーマパークなど, 規 模の大きな空調設備も含まれており, さらに自動車や半導 体製造設備の空調や循環装置も含まれている. 2007 年には (独）産業技術総合研究所のグループが札幌市役所において 実証試験を行い，LSP-01 の添加によって夏季は $47 \%$ ，冬季 は $65 \%$ の省エネルギーを達成したこと ${ }^{19)}$ がマスコミなどに よっても広く紹介された。

界面活性剂による抵抗低減による $\mathrm{CO}_{2}$ 排出量の削減への



Fig. 13. Relationship between the flow rate and the frequency of the inverter. 
寄与を国内の商用ビルに適用したとすると（適用可能な設 備は全体の $1 / 3$ と仮定), 年間 50 万トンの削減が試算される. これは, 2007 年度におけるわが国の地球温暖化ガス排出量 ( $\mathrm{CO}_{2}$ 換算 $)$ の $0.037 \%$ である. 商用ビル以外の密閉系循環 設備などを試算に加えれば，さらに削減率に寄与できるこ とがわかるであろう。

\section{7. まとめ}

レオロジーの応用分野の一つとして, 界面活性剤水溶液 のレオロジー特性を活用した省エネルギー型空調システム の開発と実用化，およびその普及について述べた。この技術 の一般的な空調設備への普及は今後とも進められ, さらに 空調設備以外の分野にも普及していくであろう。界面活性 剤は発泡するため，その利用は閉路循環系に限られている。 界面活性剂に限定されない新しい抵抗低減剤の開発がレオ ロジー研究とともに進められることが期待される.

\section{REFERENCES}

1) Shikata T, Hirata H, Langmuir, 4, 354-359 (1988).

2) Usui H, and Miura K, Proc. PPS Int. Conf. on Rheology, Seoul, 76-79 (1990).

3) Bewerdorff HW, Thiel H, Applied Scientific Research, 50, 347 (1993).

4) Gyr A, Bewerdorff HW, "Drag Reduction of Turbulent Flows by Additives"(1989) Kluwer Academic Publishers, Dordrecht, The Netherlands.

5) Ohlendorf D, Interthal W, Hoffmann H, Rheol Acta, 25, 68 (1986).
6) Bewersdorff HW, Ohlendorf D, Colloid \& Polymer Sci, 266, 941(1988).

7) Chara Z, Zakin JL, Severa, M, Myska J, Experiments in Fluids, 16, 36(1993).

8) Hoyer KW, Gyr A, Transactions of the ASME, 120, 818 (1988).

9) Itho M, Imao S, Tokuda K, Nihon Kikaigakkai Ronbunshu(B), 61, 266 (1995).

10) Kawaguchi $Y$, Tawaraya $Y$, Yabe A, Hishida K, Maeda M, FED-Vol237 ASME 1996 Fluids Eng Div Conf, 2, 45 (1996).

11) Sato K, Mimatsu J, Kumada M, Thermal Sci \& Eng, 7, 41 (1999).

12) Usui H, Kariyama H, Saeki T, Sugawara H, Wakui F, Kagakukogaku Ronbunshu, 24, 134-137 (1998).

13) Usui H, Sakai R, Ito T, Saeki T, Kagakukogaku Ronbunshu, 22, 221-225 (1996).

14) Saeki $T$, Tokuhara $K$, Matsumura $T$, Yamamoto $S$, Nihon Kikaigakkai Ronbunshu(B), 68, 1482-1488 (2002).

15) Motier JF, Prilutski DJ, Proc. $3^{\text {rd }}$ Int. Conf. on Drag Reduction, Bristor UK, F-2(1984).

16) Yashio A, Kamakura K, Hara S, Kawashima M, Tachibana M, Proc. Autumn Meeting of Air Conditioning and Sanitary Eng Soc Jap, 905-907 (1995)

17) Usui H, Itoh T, Saeki T, Rheol Acta, 37, 122-128 (1998).

18) Kawaguchi Y, Nihonkikaigakkai Ryuutaibumon Kouen Ronbunshu, F1-3, 301 (2001).

19) National Institute of Advanced Industry Science and Technology, Japan, Energy Research Div. Press release (2008.2). 